\title{
Pilot-Scale Electrocoagulation with Bipolar Aluminum Electrodes for On-Site Domestic Greywater Reuse
}

\author{
Chin-Jung Lin"; Shang-Lien $\mathrm{Lo}^{2}$; Chao-Yin Kuo ${ }^{3}$; and Chung-Hsin $\mathrm{Wu}^{4}$
}

\begin{abstract}
Designing a reclaimed water system provides an economically and environmentally favorable method for disposing of wastewater. However, some critical influences on on-site reclaimed water systems, such as limited building area, often limit the effectiveness of conventional treatment methods. This work established a compact and inexpensive electrocoagulation process with a capacity of $28 \mathrm{~m}^{3} /$ day to reclaim domestic greywater for human noncontact usage. The total unit cost of on-site domestic greywater reuse was U.S. $\$ 0.27 / \mathrm{m}^{3}$, which was below the local potable water rate. Moreover, the treatment facility required an area of $8 \mathrm{~m}^{2}$. Both unit cost and required area in this work are lower than those reported in the literature. The experimental results support the feasibility of the on-site reuse of greywater in high-rise buildings.
\end{abstract}

DOI: 10.1061/(ASCE)0733-9372(2005)131:3(491)

CE Database subject headings: Aggregation; Coagulation; Water reuse; Water reclamation; Water treatment.

\section{Introduction}

Growing demand for fresh water resources has made municipal wastewater reuse an attractive method of conserving and even increasing available water supplies. Over $50 \%$ of the water demand from domestic and industrial applications could be met by water of lower quality than fully treated water, including applications such as process water, toilet flushing, garden water, and car washing (Dieter 1996). Substituting low-quality water for nonpotable purposes to preserve limited high-quality water resources is highly efficient and practical, especially in arid regions or developing countries.

Conventional reclaimed water treatment processes are effective in integrating secondary treatment with advanced treatment methods, such as microfiltration (MF), ultrafiltration (UF), reverse osmosis (RO), and chemical coagulation. However, such processes require a large serving area for treatment facilities and professional staff for operating and maintaining these treatment

\footnotetext{
${ }^{1}$ Research Center for Environmental Pollution Prevention and Control Technology, Graduate Institute of Environmental Engineering, National Taiwan Univ., Taipei 106, Taiwan.

${ }^{2}$ Research Center for Environmental Pollution Prevention and Control Technology, Graduate Institute of Environmental Engineering, National Taiwan Univ., Taipei 106, Taiwan.

${ }^{3}$ Graduate Institute of Environmental and Safety Engineering, National Yunlin Univ. of Science \& Technology, Touliu, Yunlin, 640, Taiwan.

${ }^{4}$ Dept. of Environmental Engineering and Health, Yuanpei Institute of Science and Technology, 306 Yuanpei St., Hsinchu, Taiwan.

Note. Discussion open until August 1, 2005. Separate discussions must be submitted for individual papers. To extend the closing date by one month, a written request must be filed with the ASCE Managing Editor. The manuscript for this technical note was submitted for review and possible publication on March 6, 2002; approved on June 2, 2004. This technical note is part of the Journal of Environmental Engineering, Vol. 131, No. 3, March 1, 2005. (CASCE, ISSN 0733-9372/2005/3-491$495 / \$ 25.00$
}

facilities. The electrocoagulation process offers an alternative to the aforementioned approaches that has the advantages of compactness and economic competitiveness.

Electrocoagulation has been reported to offer various advantages over conventional coagulation, specifically in relation to hydraulic retention time, removal efficiency of ultrafine particles, coagulant dosage, sludge production, cost, and operating and maintenance simplicity (Vik et al. 1984; Pouet and Grasmick 1995; Mills 2000). An extensive amount of literature has been published on electrocoagulation in conjunction with other processes, such as dissolved air flotation (Pouet and Casmick 1995), electroflotation (Chen et al. 2000), high gradient magnetic filtration (Tsouris et al. 2001), and the use of a settling tank (Jenke and Diebold 1984), to cope with various wastewater. Few works (Beck et al. 1974; Rubach and Saur 1997) have been reported on the electrocoagulation process that directly caused colloids to be floated by hydrogen bubbles generated in the cathodes by the electrolysis of water.

This investigation developed a pilot-scale electrocoagulation process combined with direct flotation by hydrogen gas evolution in the cathodes for reclaiming domestic greywater that followed the general guidelines for water reuse for human noncontact usage. This work thus attempted to determine the total cost of the reclaimed water and the consequent payoff period. Furthermore, the proposed process was compared with other processes for greywater reuse in buildings described in the literature, with regard to both the serving area required by the treatment facility and the cost of the reclaimed water.

\section{Experimental Procedures}

\section{Description of Electrocoagulation Process}

Fig. 1 displays the layout of the electrocoagulation process, occupying approximately $8 \mathrm{~m}^{2}$ in total, for on-site domestic greywater reuse. The inlet greywater, drawn from a sinkhole, was fed 


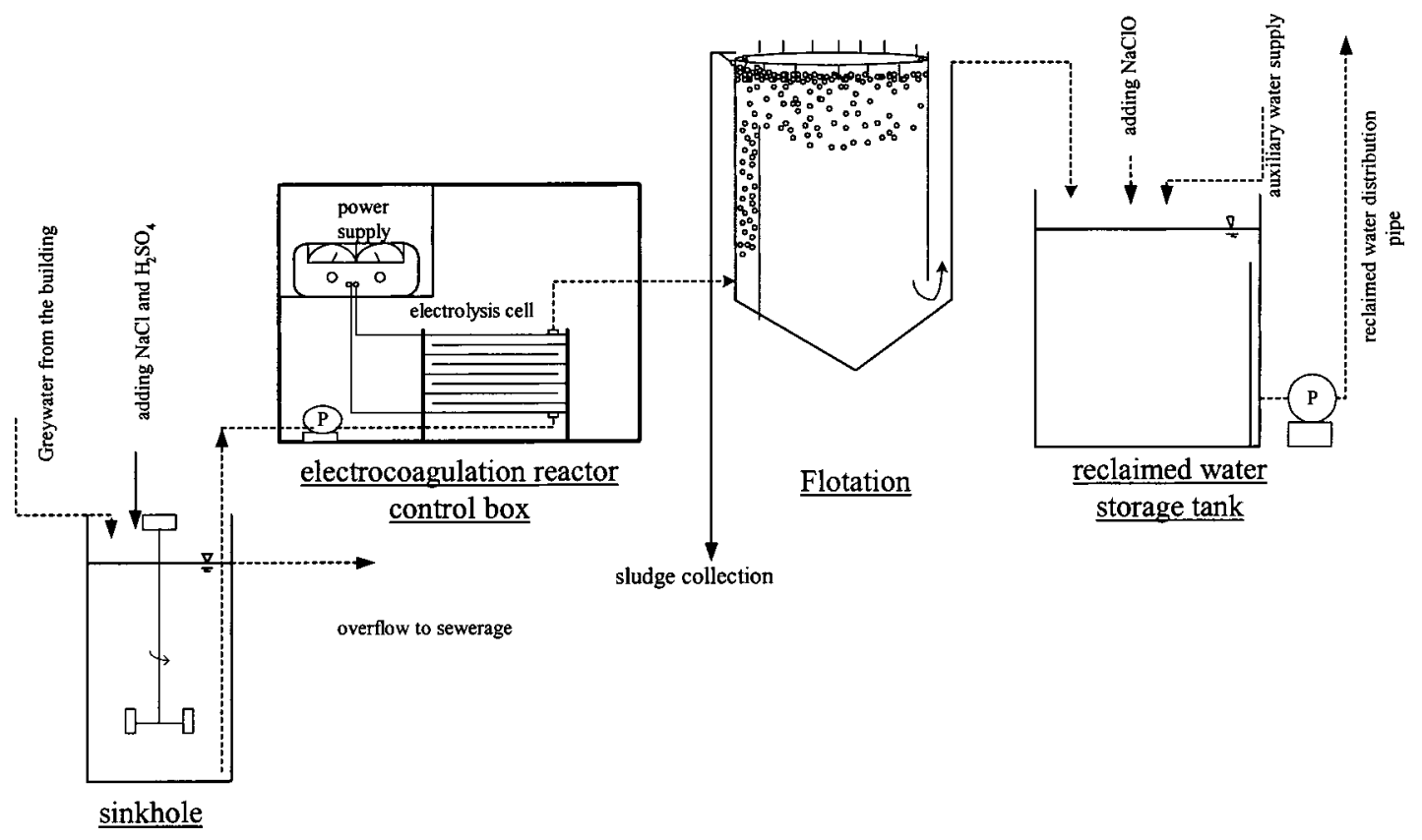

Fig. 1. Flow diagram of pilot-scale electrocoagulation process

to the electrolysis cell at $1.2-1.4 \mathrm{~m}^{3} / \mathrm{h}$, and $\mathrm{NaCl}(1 \mathrm{M})$ and $\mathrm{H}_{2} \mathrm{SO}_{4}(1 \mathrm{M})$ were added to adjust the conductivity to 500 $\sim 600 \mu \mathrm{s} / \mathrm{cm}$ and the $\mathrm{pH}$ to $6-7$, respectively. The electrolysis cell comprised a pair of outer stainless-steel monopolar electrodes and numerous inner aluminum bipolar electrodes (99\% purity), without any electric connection. The dimensions of the reactor were determined according to our previous laboratory study (Lin et al. 2002). The interelectrode distance was $10 \mathrm{~mm}$, and there were 20 horizontal-flow channels. Each plate had dimensions of $500 \times 240 \times 10 \mathrm{~mm}$, with an effective area of $1,000 \mathrm{~cm}^{2}$, given a flow velocity of $13.5 \mathrm{~cm} / \mathrm{s}$ and a contact time of $70 \mathrm{~s}$. This work used aluminum as the sacrificial anode, rather than iron, because the residual ferrous ions are easily oxidized by air in the storage tank, coloring the reclaimed water. Scum was then separated out using the flotation apparatus, and flotation was achieved by gas bubbles developed in the cathode within $15 \mathrm{~min}$ of hydraulic retention, where the top layer can be skimmed and clean water regularly tapped. The reclaimed water was disinfected with sodium hypochlorate $(\mathrm{NaClO})$ in the reclaimed water tank, an auxiliary water supply was provided, and a residual chlorine of over $0.4 \mathrm{mg} / \mathrm{L}$ was maintained.

\section{Characteristics of Domestic Greywater}

The quality of the reclaimed water in the flotation unit effluent was assessed in terms of biological oxygen demand $\left(\mathrm{BOD}_{5}\right), \mathrm{pH}$, suspension solids (SS), total solids (TS), ammonia-nitrogen $\left(\mathrm{NH}_{3}-\mathrm{N}\right)$, E. coli, residual chlorine, and chloride ion, all of which were measured using standard methods [American Public Health Association (APHA) 1992]. Chemical oxygen demand (COD) was measured using a COD reactor and a direct reading spectrophotometer (DR/2000, HACH), and the latter was also used to assess color, represented as visible absorbance at $420 \mathrm{~nm}$. Furthermore, both turbidity and conductivity were measured using a turbidimeter (2100P, HACH) and a conductivity meter (LF96B, Suntex), respectively. A particle diameter of $0.45 \mu \mathrm{m}$ was selected as the threshold for distinguishing soluble chemical oxygen demand (CODs) from total chemical oxygen demand $\left(\mathrm{COD}_{t}\right)$. Fur- thermore, a granolumeter (M175, CILAS) was used to analyze the relative percentage of particles with diameters of under $196 \mu \mathrm{m}$.

\section{Results and Discussion}

\section{Effect of Applied Voltage on Pollutants Aggregation}

Preliminary laboratory testing of the electrolysis cell involved determining the effect of applied voltage on the size distribution of particles with kaolinite suspensions as a turbidity source, using a granolumeter. Kaolinite suspensions with a small range of size distributions, namely, between 4 and $16 \mu \mathrm{m}$ (Fig. 2), were used to simulate particle pollutants of greywater. As indicated in Fig. 2, applying an electric field from 50-255 V tended to increase the particle size in the effluent. Thus, the aggregation of particles, resulting from the charge redistribution on the particle surface in the electric field, would occur in all the range of 50-255 V. However, a little degree of change in the particle size was observed when the applied voltage was increased from 136-255 V. Regarding the effectiveness and economics of this system, it is suggested the use of the voltage be below $136 \mathrm{~V}$.

\section{Effect of Aluminum Release Dosage on Pollutants Removal}

Eq. (1) expresses the theoretical aluminum concentration at the outlet of the electrolysis cell

$$
C_{\mathrm{Al}}=\frac{M_{\text {total }, \mathrm{Al}}}{V_{\text {total, liquid }}}=\frac{I \times t \times m_{\mathrm{Al}} \times N}{Q \times t}=\frac{I \times m_{\mathrm{Al}} \times N}{Q}
$$

where $C_{\mathrm{Al}}=$ dosage of released aluminum from the outlet of the electrolysis cell $(\mathrm{mg} / \mathrm{L}) ; M_{\text {total,Al }}=$ total mass of released aluminum $(\mathrm{mg})$ by Faraday's law within the retention time $(t, \mathrm{~s}$ ) ; $V_{\text {total,liquid }}=$ total volume of the effluent $(\mathrm{L})$ within the retention time: $I=$ applied current (amperes); $N=$ number of channels in the electrolysis cell; $Q=$ flow rate $(\mathrm{L} / \mathrm{s})$, and $m_{\mathrm{Al}}=$ electrochemical 


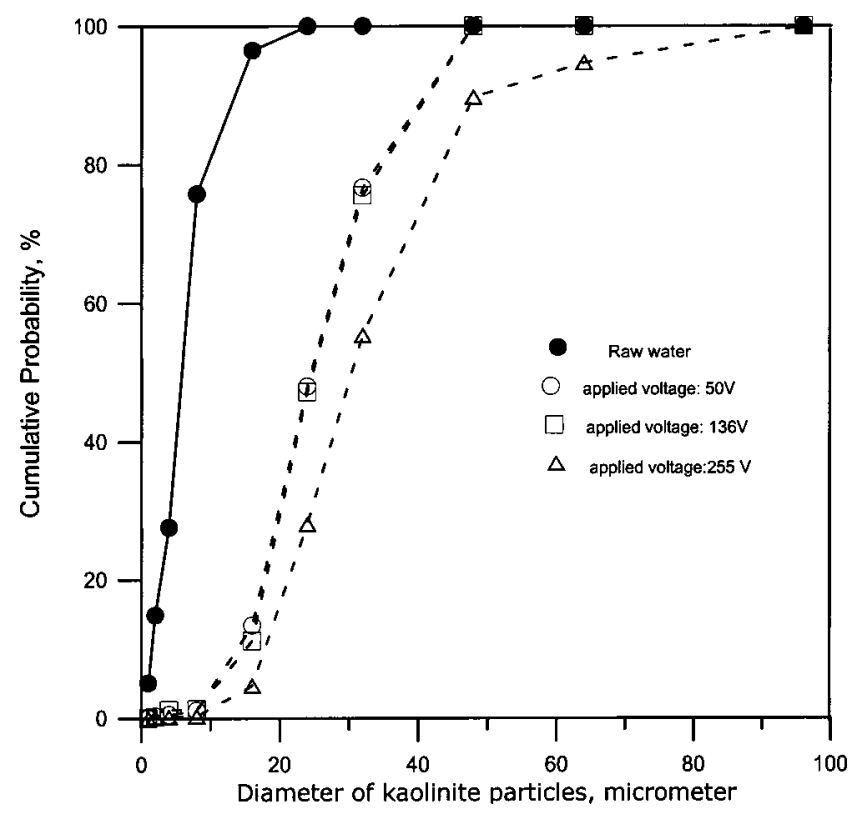

Fig. 2. Effect of applied voltage on size distribution of kaolinite suspensions: initial turbidity $=410 \mathrm{NTU}$; flow rate $=20 \mathrm{~mL} / \mathrm{s}$; applied current $=0.65 \mathrm{~A}$; number of channels $=10$; interelectrode distance $=5$ $\mathrm{mm} ; \mathrm{pH}=6.5$; contact time $=48 \mathrm{~s}$; conductivity $=423 \mu \mathrm{S} / \mathrm{cm}$

equivalent of aluminum $(0.093 \mathrm{mg} / \mathrm{C})$. Consequently, the dosage of released aluminum in the flux, like the dosage of coagulant in conventional coagulation, can be determined by adjusting the applied current and flow rate.

Given the constant flow rate, various dosages of released aluminum can be obtained by adjusting the applied current to evaluate the efficient dosage. Fig. 3 shows that residual $\mathrm{COD}_{t}$ declines as the dosage of released aluminum increased to $25 \mathrm{mg} / \mathrm{L}$, regardless of the applied voltage, where an average of $60 \% \mathrm{COD}_{t}$ removal was achieved. Raising the dosage of released aluminum to $50 \mathrm{mg} / \mathrm{L}$ did not increase $\mathrm{COD}_{t}$ removal efficiency. Meanwhile, no significant removal of residual CODs was achieved.

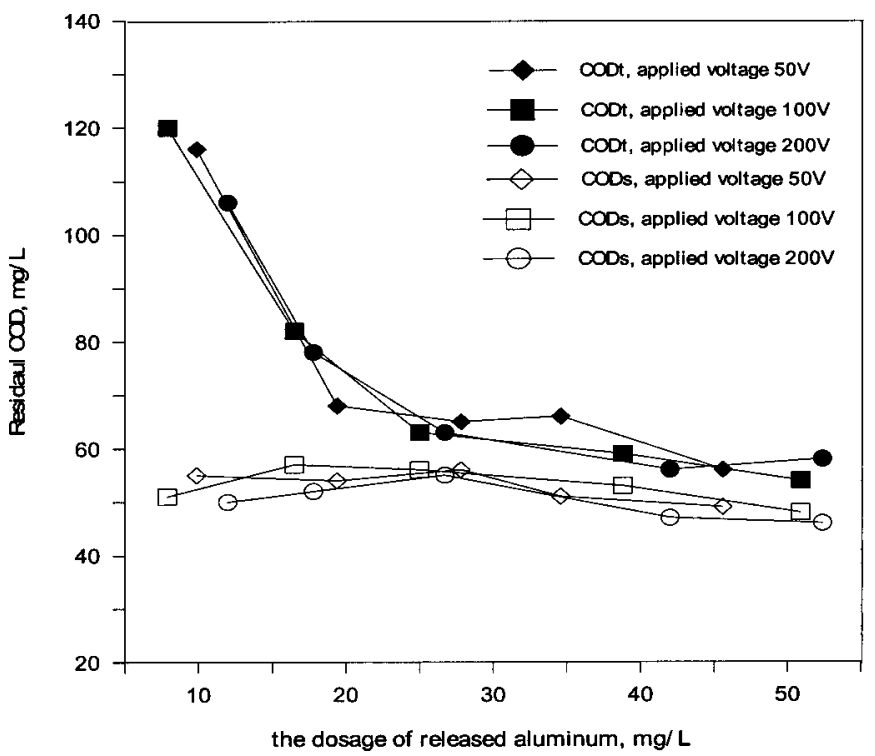

Fig. 3. Effect of released aluminum dosage on residual COD; initial total $\mathrm{COD}=128 \mathrm{mg} / \mathrm{L}$; initial soluble chemical oxygen demand $(\mathrm{COD})=76 \mathrm{mg} / \mathrm{L}$; flow rate $=34 \mathrm{~mL} / \mathrm{s}$; number of channels $=20$; interelectrode distance $=5 \mathrm{~mm} ; \mathrm{pH}=7.2$; contact time $=48 \mathrm{~s}$

COD removal efficiency was determined by the dosage of aluminum released and generally limited by the presence of soluble contaminants in the influent.

\section{Reclaimed Water Quality}

The key problem related to reclaimed water quality is to protect the public from pathogenic microorganisms. Moreover, the reclaimed water must also not be aesthetically objectionable (Asanon et al. 1996). Table 1 lists the parameters of the reclaimed water, which were monitored and considered in the light of guidelines developed for use in the United States, Japan, and China. The appearance, odor, and microorganism content of the re-

Table 1. Comparison of Reclaimed Water in Electrocoagulation Process with Reclaimed Water Quality Guidelines for Nonpotable Use

\begin{tabular}{|c|c|c|c|c|c|c|}
\hline \multirow[b]{2}{*}{ Parameter } & \multirow[b]{2}{*}{ Raw water } & \multirow[b]{2}{*}{ Reclaimed water } & \multicolumn{4}{|c|}{ Guidelines for reclaimed water quality for nonpotable use } \\
\hline & & & Taiwan $^{\mathrm{a}}$ & Japan $^{\text {b }}$ & United States $^{c}$ & China $^{\mathrm{d}}$ \\
\hline Turbidity (NTU) & $20.1-120.0(43.1)^{\mathrm{e}}$ & $1.2-17(3.6)$ & - & - & $\leqq 2$ & $\leqq 10$ \\
\hline $\mathrm{TS}(\mathrm{mg} / \mathrm{L})$ & $350-450(405)$ & $350-400(372)$ & - & - & - & - \\
\hline $\mathrm{SS}(\mathrm{mg} / \mathrm{L})$ & $15-84(29)$ & $4-19(9)$ & - & - & - & $\leqq 10$ \\
\hline Color (AMID) & 5 & $<1$ & $\leqq 40$ & Not unpleasant & - & $\leqq 30$ \\
\hline Odor & - & Not unpleasant & Not unpleasant & Not unpleasant & - & Not unpleasant \\
\hline pH & $6.5-7.5$ & $7.0-8.0$ & $6.8-8.5$ & $5.8-8.6$ & $6.0-9.0$ & $6.5-9.0$ \\
\hline $\mathrm{BOD}_{5}(\mathrm{mg} / \mathrm{L})$ & 10-41 (23) & $5-16(9)$ & $\leqq 10$ & - & $\leqq 10$ & $\leqq 10$ \\
\hline $\mathrm{COD}(\mathrm{mg} / \mathrm{L})$ & $27-102(55)$ & $14-44(22)$ & - & - & - & $\leqq 50$ \\
\hline $\mathrm{NH}_{3}-\mathrm{N}(\mathrm{mg} / \mathrm{L})$ & $0.145-0.148$ & $0.006-0.007$ & - & - & - & $\leqq 20$ \\
\hline $\mathrm{Cl}^{-}(\mathrm{mg} / \mathrm{L})$ & $180-230(206)$ & $154-178(167)$ & - & - & - & $\leqq 350$ \\
\hline $\mathrm{Cl}_{2}$ residual $(\mathrm{mg} / \mathrm{L})$ & - & $1.2-2.1(1.5)$ & Trace amount & Trace amount & $\geqq 1.0$ & $\geqq 0.2$ \\
\hline E. Coli $(\mathrm{CFU} / 100 \mathrm{~mL})$ & $3,800-5,600(5,100)$ & Not detected & $\leqq 10(\mathrm{CFU} / \mathrm{mL})$ & $<1,000$ & Not detectable & $\leqq 3 \mathrm{CFU} / \mathrm{L}$ \\
\hline
\end{tabular}

${ }^{a}$ Adapted from Taiwan Architecture and Building Research Institute 1995 guidelines; for toilet flushing.

${ }^{\mathrm{b}}$ Adapted from Japan Sewage Works Association 1993 guidelines; for toilet flushing.

${ }^{\mathrm{c}}$ Adapted from USEPA 1992 guidelines for water reuse; for urban uses, irrigation of food crops eaten raw, recreational impoundments.

${ }^{\mathrm{d}}$ Adapted from Beijing, China, 1993 guidelines for water reuse; for toilet flushing.

${ }^{\mathrm{e}}$ Average values are in parentheses. 

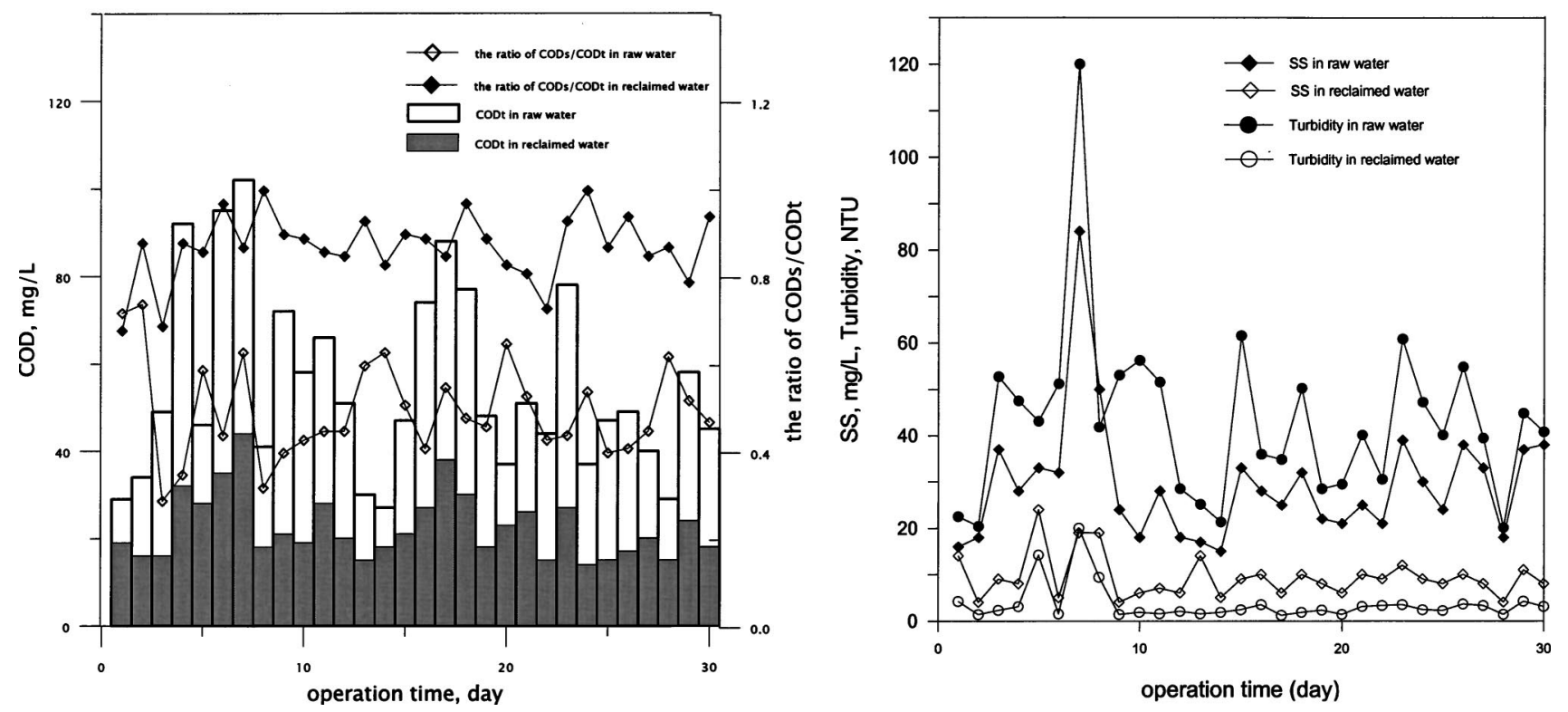

Fig. 4. Water quality of effluent from pilot-scale electrocoagulation process: (a) Chemical oxygen demand (COD) removal; (b) SS and turbidity. Operation conditions: released aluminum dosage $=20 \mathrm{mg} / \mathrm{L}$; applied voltage $=150-160 \mathrm{~V}$; flow rate $=20 \mathrm{~L} / \mathrm{min}$; number of channels $=20$; $d$ $=10 \mathrm{~mm} ; \mathrm{pH}=6.0 ;$ conductivity $=720 \mu \mathrm{S} / \mathrm{cm}$

Table 2. Estimated Cost for Pilot-Scale Electrocoagulation Process

\begin{tabular}{|c|c|c|}
\hline Item & $\begin{array}{c}\text { Cost } \\
\text { (U.S. } \$ / \mathrm{m}^{3} \text { ) }\end{array}$ & $\begin{array}{l}\text { Percentage } \\
(\%)\end{array}$ \\
\hline Capital cost & 0.08 & 29.6 \\
\hline \multicolumn{3}{|l|}{ Operational cost $\mathrm{t}^{\mathrm{a}}$} \\
\hline Electric demand $\left(0.8 \mathrm{kwh} / \mathrm{m}^{3}\right)$ & 0.07 & 25.9 \\
\hline Aluminum plate consumption & 0.04 & 14.8 \\
\hline Chemicals & 0.02 & 7.4 \\
\hline Sludge treatment & 0.06 & 22.3 \\
\hline Total operational cost & 0.19 & \\
\hline Total unit cost & 0.27 & 100 \\
\hline
\end{tabular}

${ }^{\mathrm{a}}$ Assuming a depreciation period of 10 years and an interest rate of $5 \%$. The aluminum plate costs U.S. $\$ 2 / \mathrm{kg}$, and electricity costs are U.S. $\$ 0.09 / \mathrm{kwh}$. The quantity of wet sludge treated in the electrocoagulation process was $4.0-7.0 \mathrm{~kg} / \mathrm{m}^{3}$. The constant applied current is $3 \mathrm{~A}$, and the average applied voltage is $135 \mathrm{~V}$. claimed water in the pilot-scale electrocoagulation process satisfied the general guidelines. As indicated in Fig. 4, the ratios of $\mathrm{COD}_{s}$ and $\mathrm{COD}_{t}$ ranged from 0.3 to 0.6 in the influent and from 0.8 to 1.0 in the effluent. Moreover, the $\mathrm{COD}_{t}$ of the effluent was related to the $\mathrm{COD}_{s}$ of the influent, suggesting that electrocoagulation easily removes particulate organic matter and slightly reduces soluble organic matter. Thus, suspension solids were easily removed from the solution at a high efficiency.

\section{Reclaimed Water Cost}

When optimized, the total cost for on-site domestic greywater reuse by electrocoagulation is U.S. $\$ 0.27 / \mathrm{m}^{3}$ (Table 2). In this pilot site, the local average potable water rate is U.S. $\$ 0.3 / \mathrm{m}^{3}$ and the operational cost of reclaiming water is U.S. $\$ 0.19 / \mathrm{m}^{3}$. The use of reclaimed water to reduce demand for potable water achieves a direct economic benefit of U.S. $\$ 0.11 / \mathrm{m}^{3}$, which is the difference between the cost of local potable water and the

Table 3. Comparison of This Work with Other Cases in Treatment Method, Flow Rate, Required Area, and Unit Cost

\begin{tabular}{|c|c|c|c|c|c|c|}
\hline Location & $\begin{array}{c}\text { Type of reclaimed } \\
\text { water system }\end{array}$ & Treatment facility & $\begin{array}{l}\text { Flow rate } \\
\left(\mathrm{m}^{3} / \text { day }\right)\end{array}$ & $\begin{array}{l}\text { Purpose } \\
\text { of reclaimed } \\
\text { water }\end{array}$ & $\begin{array}{l}\text { Serving } \\
\text { space } \\
\text { for treatment } \\
\text { facility } \\
\left(\mathrm{m}^{2}\right)\end{array}$ & $\begin{array}{l}\text { Unit cost } \\
\left(\text { U.S. } \$ / \mathrm{m}^{3}\right)\end{array}$ \\
\hline Tokyo, Japan & Individual building & Biological oxidation, ultrafiltration & 180 & Toilet flushing & - & 1.80 \\
\hline Germany $^{\mathrm{a}}$ & Individual building & Biological oxidation, microfiltration, UV & 1 & Toilet flushing & - & 1.05 \\
\hline Tokyo, Japan ${ }^{\mathrm{b}}$ & Individual building & Aeration tank, ultrafiltration & 110 & Toilet flushing & 45 & - \\
\hline Tokyo, Japan ${ }^{\mathrm{b}}$ & Individual building & Biological oxidation, microfiltration & 154 & Toilet flushing & 285 & - \\
\hline Fukuoka, Japan ${ }^{\mathrm{c}}$ & Regional dual water system & Biological oxidation, sand filtration, ozonation & 8,000 & Toilet flushing & - & 3.5 \\
\hline Taipei, Taiwan & This study & Electrocoagulation & 28 & Toilet flushing & 8 & 0.27 \\
\hline
\end{tabular}

\footnotetext{
${ }^{\mathrm{a}}$ Adapted from Dieter (1996).

${ }^{\mathrm{b}}$ Adapted from Shiao and Chen (1994).

${ }^{\mathrm{c}}$ Adapted from Asano et al. (1996).
} 
operational cost of water reclamation. Meanwhile, the payoff period is 5.5 years and is determined mainly by the difference between the costs of potable and reclaimed water.

Four cases of water reclamation systems in individual buildings and one case of a regional dual water system exist for comparison with the system presented here. Table 3 reveals that the unit cost of a regional dual water system exceeds that of a dual water system in an individual building. Reclaimed water obtained using the system presented in this work is cheaper than that obtained in similar cases. The most important advantage of the building-based dual water system is that the electrocoagulation process does not require a lot of space in such a system.

\section{Conclusions}

Electrocoagulation is a viable alternative for on-site reuse of greywater in individual buildings. COD removal efficiency was determined by the dosage of aluminum released and is generally restricted by the presence of soluble contaminants in the influent. Furthermore, this pilot-scale process reclaimed domestic greywater at $28 \mathrm{~m}^{3} /$ day, meeting the general guidelines for water in human noncontact usage. The cost was U.S. $\$ 0.27 / \mathrm{m}^{3}$, and the treatment facility required an area of $8 \mathrm{~m}^{2}$. Utilizing water of appropriate quality reduces the difference between water and wastewater, helping them to be ultimately recognized as the same natural resource.

\section{Acknowledgment}

The writers would like to thank the Architecture and Building Research Institute, Ministry of the Interior, for financially supporting this research.

\section{Notation}

The following symbols are used in this paper:

$C_{\mathrm{Al}}=$ dosage of released aluminum from outlet of electrolysis cell $(\mathrm{mg} / \mathrm{L})$;

$I=$ applied current (amperes);

$$
\begin{aligned}
M_{\mathrm{total}, \mathrm{Al}}= & \text { total mass of released aluminum by Faraday's } \\
& \text { law within retention time }(t)(\mathrm{mg}) ; \\
m_{\mathrm{Al}}= & \text { electrochemical equivalent of aluminum } \\
& (0.093 \mathrm{mg} / \mathrm{C}) ; \\
N= & \text { number of channels in electrolysis cell; } \\
Q= & \text { flow rate }(\mathrm{L} / \mathrm{s}) ; \text { and } \\
V_{\text {total,liquid }}= & \text { total volume of effluent within retention time } \\
& (\mathrm{L}) .
\end{aligned}
$$

\section{References}

American Public Health Association (APHA). (1992). Standard methods for examination of water and wastewater, 17th Ed., Washington, D.C.

Asano, T., Maeda, N., and Takaki, M. (1996). "Wastewater reclamation and reuse in Japan: overview and implementation examples." Water Sci. Technol. 34, 219-226.

Beck, E. C., Giannini, A. P., and Ramirez, E. R. (1974). "Electrocoagulation clarifies food wastewater." J. Food Technol., 2, 18-22.

Chen, G., Chen, X., and Yue, P. L. (2000). "Electrocoagulation and electroflotation of restaurant wastewater." J. Environ. Eng., 126(9), 858863.

Dieter, K. (1996). "Jerkwater recycling: Treatment techniques and cost saving." World Water Environ. Eng., 2, 18-19.

Lin, C. J., Lo, S. L., and Kuo, C. Y. (2002). "Feasibility study of applying electrocoagulation to grey water reuse in buildings." Adv. Asian Environ. Eng., 2, 52-58.

Jenke, D. R., and Diebold, F. E. (1984). "Electroprecipitation treatment of acid mine wastewater." Water Res., 22, 231-233.

Mills, D. (2000). "A new process for electrocoagulation.” J. Am. Water Works Assoc., 92, 34-43.

Pouet, M. F., and Grasmick, A. (1995). "Urban wastewater treatment by electrocoagulation and flotation." Water Sci. Technol. 31, 275-283.

Rubach, S., and Saur, I. F. (1997). "Onshore testing of produced water by electroflocculation.” Filtr. Sep., 10, 877-882.

Shiao, S. H., and Chen, R. F. (1994). "Development and application of reclaimed water techniques." Energy Resource Environ., 7, 34-42.

Tsouris, C., DePoli, D. W., Shor, J. T., Hu, M. Z.-C., and Ying, T.-Y. (2001). "Electrocoagulation for magnetic seeding of colloidal particles." Colloids Surf., A, 177, 223-233.

Vik, E. A., Carison, D. A., Eikum, A. S., and Gjessing, E. T. (1984). "Electrocoagulation of potable water." Water Res., 18, 1355-1360. 